\title{
PENANAMAN PENDIDIKAN LIFE SKILL DALAM MENINGKATKAN KEMANDIRIAN SANTRI BARU DI PONDOK MODERN GONTOR PUTRA II PONOROGO
}

\author{
Muhammad Nizhomun Niam \\ Institut Agama Islam Negeri Surakarta \\ E-Mail: bosterholic@@gmail.com
}

\begin{abstract}
The aims of this study are to describe the cultivation of life skill education to improve new students' independence in Pondok Modern Darussalam Gontor Putra (PMDG) II, Madusari, Siman, Ponorogo Year 2017/2018. The discussion of this study covers the strategy, implementation, also the obstacles and the supporting factors. The type of this study is qualitative research. The subjects of this study are consists of the head master of PMDG, the director of KMI, the teachers, and the students of PMDG Campus II. The object of this study is PMDG Campus II. The data are collected through observation, interviews, and documentation. While the analysis technique is descriptive qualitative. Meanwhile, the validity is determined by triangulation. The results of this study showed that: (1) the cultivation of life skill education to improve new students' independence in Pondok Modern Darussalam Gontor Putra (PMDG) II are consists of: a. Ensuring the goal; $b$. set the steps for earning the goal; $c$. Using some personal approaches; and d. Establish a measuring instrument to measure the success of life skill education to improve new students' independence. (2) the implementation of life skill education are consists of personal skills aspects $b$. thinking skill aspects $c$. social skills aspects $d$. vocational skills aspects And (3) the obstacles in implementing of life skill education to improve new students' independence in PMDG Campus II are: the new students' emotion are still unstable, the supervision of dormitory counselors toward the new students are limited, to get used to PMDG activities are difficult for the new students, the lack of awareness of new students in maintaining the facilities and infrastructure, and the limited capacity of students' rooms. On the other hand, implementing life skill education to improve new students' independence in PMDG has supporting factors such as the education integration such as formal, non-formal, and in-formal education platforms, the existence of new students at PM Gontor Putra II is to learn, transform the life skill education, and activity-based are lasting all year.
\end{abstract}

Keywords: cultivation; life skill education; new students' independence.

Abstrak: Penelitian ini bertujuan untuk mendiskripsikan penanaman pendidikan life skill dalam meningkatkan kemandirian santri baru di Pondok Modern Darussalam Gontor Putra II, Madusari, Siman, Ponorogo Tahun 2017/2018 yang meliputi strategi penanaman, implementasi, dan faktokpendukung dan penghambatnya. Jenis penelitian ini adalah penelitian kualitatif. Subjek penelitian ini terdiri dari Pengasuh Pondok, Direktur KMI, Asatidz, dan Santri Pondok Modern Darussalam Gontor Putra II. Objek penelitian ini adalah Pondok Modern Darussalam Gontor Putra II, Madusari, Siman, Ponorogo. Teknik pengumpulan data melalui observasi, wawancara, dan dokumentasi. Keabsahan ditentukan dengan triangulasi. Teknik analisis data secara deskriptif kualitatif. Hasil penelitian menunjukkan bahwa (1) strategi yang digunakan terdiri dari a. Adanya tujuan yang jelas; $b$. Menetapkan langkahlangkah/cara-cara; c. Menggunakan pendekatan-pendekatan; dan d. Menetapkan tolak ukur untuk menentukan keberhasilan dalam menanamkan pendidikan life skill untuk meningkatkan kemandirian santri baru. (2) implementasi terdiri dari a. aspek personal skill b. aspek tinking skill c. aspek social skill d. aspek vocasional skill (3) Faktor penghambat dan pendukung terdiri 
dari faktor penghambat meliputi: santri baru masih memiliki tingkat emosional yang masih labil, belum maksimalnya pengawalan terhadap santri baru oleh pembimbing rayon, masih sulitnya santri baru untuk menyesuaikan diri dengan kegiatan-kegiatan Pondok, kurangnya kepedulian santri baru dalam menjaga sarana dan prasarana, dan daya tampung kamar santri terbatas; dan faktor pendukung, meliputi: terintegrasinya tripusat pendidikan, integrasi jalur pendidikan formal, non-formal, dan in-formal, keberadaan santri baru di PM Gontor Putra II adalah menuntut ilmu, transformasi penanaman pendidikan life skill dalam meningkatkan kemandirian santri baru berlangsung sepanjang tahun, dan berbasis kegiatan.

Kata Kunci: penanaman; pendidikan life skill; kemandirian santri baru

\section{PENDAHULUAN}

Pendidikan Islam harus mampu membentuk peserta didik untuk membangun dirinya sendiri, dengan membekali peserta didik agar mampu hidup dengan kemampuan masing-masing. Semakin maraknya angka pengangguran disetiapjenjang pendidikandan pemberitaan di televisi terkait pembegalan, pencurian, perampokan, dan penyelundupan narkoba merupakan salah satu akibat dari lemahnya ekonomi dan keimanan seseorang, sehingga menghalalkan berbagai cara untuk mendapatkan uang. Selain itu, mereka juga kurang mengembangkan keterampilan sehingga kurang mampu bersaing di era modern yang penuh dengan ide kreativitas dan inovasi. Fenomena-fenomena tersebut menuntut khususnya pada dunia pendidikan Islam untuk mengembangkan kemandirian peserta didik.

Sebagai lembaga pendidikan tradisional di Negara Indonesia, Pondok Pesantren masih tetap konsisten dalam mendidik peserta didiknya menggunakan sarana keteladanan, penciptaan lingkungan yang kondusif, pembiasaan yang baik, serta kegiatan yang terarah dalam mengembangkan kemandirian peserta didiknya dalam berprilaku sehari-hari. ${ }^{1}$ Dalam mengimplementasikan kemandirian di Pondok Pesantren terhadap santri, tidak cukup dengan mengandalkan ceramah dan pengarahan, namun juga dikuatkan dengan keteladanan dan penciptaan miliu yang

1 Ahmad Suharto, Senarai Kearifan Gontory (Kata Bijak Para Perintis dan Masyayikh Gontor), (Yogyakarta: YPPWP Guru Muslich, 2016), hlm. 127 kondusif, sehingga semua apa yang dilihat peserta didik dan didengarkannya berupa gerakan dan suara-suara, merupakan faktor pendukung dalam meningkatkan kemandirian santri di Pondok Pesantren.

Kemandirian yang diterapkan di Pondok Pesantren, merupakan pengenjawatahan dari filsafat kepompong, dimana santri berevolusi menjadi lebih baik dalam memperjuangkan masa depannya yang gemilang, dan mampu berdiri sendiri tanpa mengharapkan santunan orang lain untuk keluar dari belunggu kepompong, karena disitu ada proses penguatan daya tahan, daya juang, daya saing, daya suai, dan daya kreatif. Sebagaimana yang dikemukakan oleh Ahmad Suharto, bahwa: "Pondok Pesantren mengutamakan pendidikan kemandirian, mendidik santri untuk selalu "al-I'timad alan nafsi", pandai menolong diri sendiri, tidak bergantung dengan orang lain, tetapi selalu belajar untuk mencukupi kebutuhan diri sendiri. Santri yang terdidik menolong diri sendiri, dapat menghadapi masa depan dengan penuh harapan, jalan hidup terbentang luas di mukanya. Sebaliknya pemuda yang tidak percaya pada dirinya, dia senantiasa was-was dan ragu-ragu, serta tidak akan mendapat kepercayaan dari masyarakat, sedang dia sendiri tidak percaya kepada dirinya sendiri". ${ }^{2}$

Hal diatas, diperkuat dengan UndangUndang No.20, Tahun.2003, tentang sistem pendidikan Nasional, Bab.2, Pasal:3, bahwa: "Pendidikan nasional

2 Ahmad Suharto, Melacak Akar Filosofis Pendidikan Gontor (Kajian Metamorfosis Syajarah Thayyibah Gontor), (Yogyakarta: Nabela, 2017), 
berfungsi mengembangkan kemampuan dan membentuk watak serta peradaban bangsa yang bermartabat dalam rangka mencerdaskan kehidupan bangsa, bertujuan untuk berkembangnya potensi peserta didik agar menjadi manusia yang beriman dan bertakwa kepada Tuhan Yang Maha Esa, berakhlak mulia, sehat, berilmu, cakap, kreatif, mandiri, dan menjadi warga negara yang demokratis serta bertanggung jawab". ${ }^{3}$

Berdasarkan ungkapan Ahmad Suharto dan Undang-Undang diatas, sebenarnya kemandirian santri yang ditekankan di Pondok Pesantren dan Negara Indonesia memiliki kesamaan dalam pencapaiannya, yaitu agar santri mampu berdiri sendiri tanpa bantuan orang lain menghadapi segala rintangan problematika kehidupannya sehari hari, membentuk kepribadian mandiri, percaya pada kemampuan dan potensi diri sendiri, hingga mandiri dalam belajar, dalam berpikir, dan pengembangan diri sendiri. Dan untuk memopang kemandirian santri juga dibekali dengan berbagai macam ilmu, wawasan, kepernahan pengalaman, keterampilan, dan kecakapan, namun penekanannya tetap pada mental skill dan bukan job skill.

Kemandirian santri merupakan suatu sikap yang sangat diperlukan oleh santri dalam menjalani aktivitas kehidupannya, sebaliknya ketergantungan kepada orang lain adalah sifat yang kurang baik bagi santri, karena santri akan melahirkan sifat malas dan lemah semangat serta enggan berusaha, yang pada akhirnya akan merugikan santri sendiri dan orang lain, karena santri pada hakekatnya adalah "sendiri", akan kembali ke asalnya sendiri, dan mempertanggung jawabkan semua amalnya juga sendiri, tanpa ada seorangpun yang sanggup membantu dan menemani santri tersebut. ${ }^{4}$

Santri dalam kehidupan sehari-hari,

3 Undang-Undang Sistem Pendidikan Nasional, (Jakarta: CV. Eko Jaya, 2003), hlm.7

4 Juwariyah, Pendidikan Moral dalam Puisi Imam Syafi'i dan Ahmad Syauqi, (Yogyakarta: Bidang Akademik, 2008), hlm.174 tidak akan selamanya menggantungkan hidupnya pada orang lain. Tidak ada yang hidup abadi di dunia ini. Oleh sebab itu, santri hendaknya dididik untuk mampu mandiri, dengan dibiasakan untuk mengerjakan sesuatu yang sudah dapat dilakukannya sendiri. Namun, dalam hal ini kemandirian santri jika tidak didukung dengan pendidikan life skill maka tidak akan berjalan dengan baik, karena pendidikan life skill merupakan pendukung dan penunjang dalam membentuk kepribadian santri untuk lebih mandiri (dapat menghidupi diri sendiri bahkan orang lain dengan life skill yang dimilikinya). ${ }^{5}$ Sebagaimana firman Allah SWT, dalam surat An-Nisa, ayat:9, yang berbunyi:

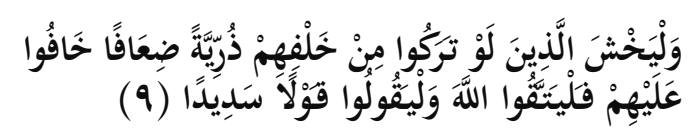

\begin{abstract}
Artinya:
Dan hendaklah takut kepada Allah orangorang yang seandainya meninggalkan dibelakang mereka anak-anak yang lemah, yang mereka khawatir terhadap (kesejahteraan) mereka. Oleh sebab itu hendaklah mereka bertakwa kepada Allah dan hendaklah mereka mengucapkan perkataan yang benar.(Q.S An-Nisa, ayat:9) 6
\end{abstract}

Hal di atas, sangalah penting untuk dilaksanakan dalam meningkatkan kemandirian santri, dikarenakan adanya kecenderungan dikalangan pendidik saat ini, terlalu banyak memberikan proteksi yang tinggi kepada santrinya dalam melakukan apapun yang ingin mereka lakukan, dan cenderung berlebihan, yang mengakibatkan santri terlalu bergantungan terhadap bantuan orang lain. ${ }^{7}$ Sebagaimana firman Allah SWT, dalam surat Ar-Raad,

5 Helmawati, Pendidikan Keluarga Teoritis dan Praktis, (Bandung: Remaja Rosdakarya, 2014), hlm.164

6 Tim Kreatif al-Ikhlâs, Al-Qur'an Terjemah Al-Ikhlâs, (Jakarta Pusat: Samad, t.h), hlm. 78

7 Ngainun Naim, Character Building, (Jogjakarta: Ar-Ruzz Media, 2012), hlm.164 
Ayat:11, yang berbunyi:

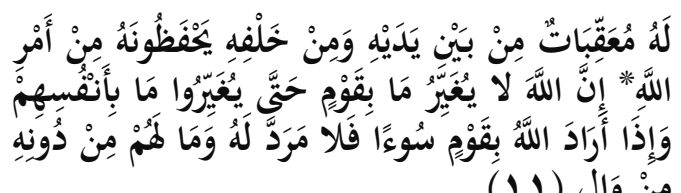

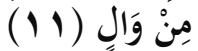

\section{Artinya:}

Baginya (manusia) ada malaikatmalaikat yang selalu menjaganya bergiliran, dari depan dan belakangnya. Mereka menjaganya atas perintah Allah. Sesungguhnya Allah tidak akan mengubah keadaan suatu kaum sebelum mereka mengubah keadaan diri mereka sendiri. Dan apabila Allah menghendaki keburukan terhadap suatu kaum, maka tidak ada yang dapat menolaknya dan tidak ada pelindung bagi mereka selain Dia. .(Q.S Ar-Raad, $: 11,)^{8}$

Dari ayat tersebut menegaskan bahwa Allah SWT tidak merubah nasib suatu kaum, sebelum kaum itu yang gigih mengubah nasibnya sendiri. Manusia diberi kemampuan oleh Allah SWT untuk mengubah nasibnya sendiri. ${ }^{9}$ Artinya kita sebagai manusia tanpa disadari telah diberikan life skill oleh Allah SWT, agar mampu untuk hidup mandiri dalam mengarungi kehidupan di dunia ini dan berusaha agar tidak bergantung kepada orang lain. Jika ingin sukses maka kita perlu berusaha untuk meraihnya, tidak hanya berdiam menunggu bantuan orang lain.

Pondok Pesantren, sebagaimana tertuang pada, Peraturan Pemerintah, No.55, Tahun.2007, tentang Pendidikan Agama dan Pendidikan Keagamaan dalam Pasal.1, yang berbunyi:"Lembaga pendidikan keagamaan Islam berbasis masyarakat yang menyelenggarakan pendidikan diniyah atau secara terpadu dengan jenis pendidikan lainnya. Sebagai lembaga pendidikan, pendidikan di pesantren ditujukan untuk menanamkan

8 Tim Kreatif al-Ikhlâs, Al-Qur'an Terjemah Al-Ikhlâs, (Jakarta Pusat: Samad, t.h), hlm. 250

9 Abdullah Gymnastiar, Malu jadi Benalu, (Bandung: MQ Publishing, 2003), hlm.12 keimanan dan ketakwaan kepada Allah SWT, akhlak mulia, serta tradisi pesantren untuk mengembangkan kemampuan, pengetahuan, dan life skill peserta didik untuk menjadi ahli ilmu agama Islam dan menjadi muslim yang memiliki life skill untuk membangun kehidupan yang islami di masyarakat". ${ }^{10}$

Salah satu Pondok Pesantren yang di dalam kesehariannya, menanamkan pendidikan life skill dalam meningkatkan kemandirian santrinya yaitu: Pondok Modern Darussalam Gontor Putra II Madusari Siman Ponorogo. Dimana penanaman pendidikan life skill di Pondok ini, mengarah kepada aspek pembentukan perilaku yang dilaksanakan dengan pendidikan by talking and by doing, pemberian tugas, pembiasan, pelatihan, pengawalan, dan penciptaan miliu. Tujuaannya adalah untuk mewujudkan generasi yang unggul demi terwujudnya khairu ummah yang berbudi tinggi, berbadan sehat, berpengetahuan luas, dan berpikiran bebas, serta mampu menjadi warga Negara Indonesia yang selalu beriman dan bertakwa kepada Allah SWT.

Penanaman pendidikan life skill dalam meningkatkan kemandirian santri baru di Pondok Modern Darussalam Gontor Putra II (PM Gontor Putra II) diterapkan dengan sistem klasikal dan berasrama penuh, dimana kyai sebagai sentral figurnya dan masjid sebagai pusat miliu yang menjiwai dan pusat kegiatan, keteladanan figuritas kyai dalam segala hal, pembinaan hidup berasrama dengan mengandalkan penciptaan miliu yang edukatif serta kegiatan yang komprehensif selama kurang lebih 24 jam, baik akademis maupun non akademis.

Penanaman pendidikan life skill PM Gontor Putra II, dilakukan dengan menciptakan berbagai macam kegiatan, meliputi: kepramukaan, kesenian, keterampilan, muhadhoroh (latihan pidato),

10 Suryadharma Ali, Mengawal Tradisi Meraih Prestasi; Inovasi dan Aksi Pendidikan Islam, (Malang: UIN-Maliki Press, 2013), hlm.159-160 
muhadhasah (percakapan bahasa Arab dan Inggris), olahraga, dan keorganisasian. Semua kegiatan tersebut, dijalankan oleh santri sendiri dan terbimbing oleh Dewan Guru di PM Gontor Putra II, sehingga dapat memberikan bekal bagi santri untuk kehidupan yang aplikatif dan dapat menjadi sumber inspirasi bagi santri ketika kembali ke masyarakat serta dapat terlaksana dengan terencana, terarah, dan terpantau.

Jadi, penanaman pendidikan life skill dalam meningkatkan kemandirian santri baru di PM Gontor Putra II, dilakukan dengan berbagai macam kegiatan, dimana kegiatan tersebut, diyakini dapat menumbuhkan dinamika kehidupan santri yang tinggi, membentuk kepribadian santri yang militansi, menimbulkan kreatifitas dan produktivitas santri, serta menimbulkan etos kerja santri yang tinggi. Pada akhirnya, santri PM Gontor Putra II akan mempunyai kemandirian yang dinamis, kreatif, dan produktif.

Rumusan masalah dalam penelitian ini adalah Bagaimana strategi penanaman pendidikan life skill dalam meningkatkan kemandirian santri baru di Pondok Modern Darussalam Gontor Putra II, Madusari, Siman, Ponorogo, Bagaimana implementasi penanaman pendidikan life skill dalam meningkatkan kemandirian santri baru di Pondok Modern Darussalam Gontor Putra II, Madusari, Siman, Ponorogo, Apa saja faktor penghambat dan pendukung penanaman pendidikan life skill dalam meningkatkan kemandirian santri baru di Pondok Modern Darussalam Gontor Putra II, Madusari, Siman, Ponorogo.

Berdasarkan hasil penelusuran dari berbagai pustaka dan karya ilmiah terdahulu, terdapat beberapa penelitian yang secara tidak langsung bersangkutan atau bersangkutan dengan penelitian yang dibahas di atas, yaitu beberapa tesis yang telah ditulis diantaranya: Implementasi Pendidikan Life Skill Di SMK Batik 1 Surakarta oleh Eka Ester Yustiningrum, Pendidikan enterpreunership dan jiwa kemandirian santri di Pondok Pesantren Sidogiri Pasuruan dan Pondok Pesantren Riyadlul Jannah Pacet Mojokerto oleh Machbub Ainur Rofiq, Manajemen Strategi Pelaksanaan Life Skills Santri di Pondok Pesantren Darul Ilmi Banjarbaru oleh Jamal Ripani, Manajemen pendidikan life skills dalam membina kemandirian vokasional santri (Studi Di Pondok Pesantren Babussalam Kabupaten Kapuas) oleh Evi Susanti, Edupreneurship Sebagai Usaha Pembentukan Karakter Kemandirian Santri (Studi Kasus di Pondok Pesantren al-Urwatul Wutsqo Jombang) oleh Ahsanatul Khulailiyah. Dan juga beberapa jurnal diantaranya: Pendidikan Kemandirian di Pondok Pesantren (Studi Mengenai Realitas Kemandirian Santri Di Pondok Pesantren Al-Istiqlal Cianjur Dan Pondok Pesantren Bahrul Ulum Tasikmalaya) oleh Uci Sanusi, Implementasi Life Skill pada Pembelajaran Kimia Bahan Aditif oleh Nurfina Aznam, Effectiveness of A Life Skills Programme On Teacher Trainees oleh Sarika Chauhan, Vallabh Vidyanagar, Life skill based education for sustainable future of adolescent girls oleh Deepika Anand and R. K. Anuradha, Reconceptualised life skills in secondary education in the African context: Lessons learnt from reforms in Ghana oleh Kwame Akyeampong. Berdasarkan beberapa penelitian di atas, peneliti banyak menemukan beberapa hal yang berkaitan dengan kemandirian santri dan life skill, namun belum ada yang meneliti dan membahas tentang penanaman pendidikan life skill dalam meningkatkan kemandirian santri baru di Pondok Pesantren. Menurut penulis, pendidikan life skill merupakan sebagian dari pendidikan yang diterapkan di Pondok Pesantren bagi santrinya, dimana pendidikan life skill di Pondok Pesantren telah mampu membentuk kemandirian santri, terlihat dari bagaimana mereka melaksanakan berbagai macam kegiatan kehidupan sehari-hari di Pondok Pesantren, terlebih dari hal ini, pendidikan life skill juga bekal yang sangat penting bagi mereka dalam menghadapi tantangan kehidupan di masyarakat setelah mereka menyelesaikan pendidikan dan pengajarannya di Pondok Pesantren. Hal inilah yang menjadikan penulis tertarik untuk melakukan penelitian tentang "Penanaman Pendidikan Life Skill 
dalam Meningkatkan Kemandirian Santri Baru di Pondok Modern Darussalam Gontor Putra II Madusari Siman Ponorogo", ini juga yang menjadikan penelitian ini berbeda dari penelitian yang terdahulu.

Berdasarkan konteks penelitian yang telah dipaparkan di atas, masalah pokok yang hendak dijawab dalam penelitian ini adalah penanaman pendidikan life skill untuk meningkatkan kemandirian santri baru di PM Gontor Putra II, Madusari, Siman, Ponorogo. Untuk memudahkan penelitian, maka rumusan masalah yang ingin dicari jawabannya dalam penelitian ini adalah sebagai berikut: 1. Bagaimana strategi penanaman pendidikan life skill dalam meningkatkan kemandirian santri baru di PM Gontor Putra II?; 2. Bagaimana implementasi penanaman pendidikan life skill dalam meningkatkan kemandirian santri baru di PM Gontor Putra II?, dan 3. Apa saja faktor penghambat dan pendukung penanaman pendidikan life skill dalam meningkatkan kemandirian santri baru di PM Gontor Putra II?

Adapun tujuan yang ingin dicapai dari penelitian ini adalah untuk mengetahui: a. Strategi penanaman pendidikan life skill dalam meningkatkan kemandirian santri baru di PM Gontor Putra II, b. Implementasi penanaman pendidikan life skill dalam meningkatkan kemandirian santri baru di PM Gontor Putra II, dan c.Faktor penghambat dan pendukung penanaman pendidikan life skill dalam meningkatkan kemandirian santri baru di PM Gontor Putra II.

\section{METODE PENELITIAN}

Penelitian ini termasuk penelitian lapangan (field research), sebab data yang dikumpulkan terhadap objek yang bersangkutan secara langsung. Penelitian ini merupakan penelitian yang bersifat deskriptif kualitatif, yakni dengan prosedur penelitian yang menghasilkan data deskriptif berupa kata-kata tertulis atau lisan dari orang-orang yang diperlukan agar dapat diamati yang dilakukan dalam kehidupan yang nyata dan sebenarnya, ${ }^{11}$ serta mendekspripsikan dan menganalisis fenomena, peristiwa, aktivitas sosial, sikap, kepercayaan, persepsi, dan pemikiran orang baik secara individu maupun kelompok. ${ }^{12}$ Peneliti melakukan penelitian terhadap "Penanaman Pendidikan Life Skill Dalam Meningkatkan Kemandirian Santri Baru Di Pondok Modern Gontor Putra II, Madusari, Siman, Ponorogo" Pendekatan yang digunakan dalam penelitian ini pendekatan fenomenologis, ${ }^{13}$ yaitu: menggambarkan data dengan apa adanya. Metode pengumpulan data menggunakan metode menggunakan tiga jenis teknik pengumpulan data, yaitu observasi, wawancara, dan dokumentasi.

\section{HASIL DAN PEMBAHASAN}

Strategi Penanaman Pendidikan Life Skill dalam Meningkatkan Kemandirian Santri Baru di PM Gontor Putra II.

Strategi secara makro berarti kebijakan-kebijakan yang mendasar dalam pengembangan pendidikan life skill sehingga tercapai tujuan pendidikan life skill secara lebih terarah, efektif, dan efesien. Jika dilihat secara mikro, maka strategi penanaman pendidikan life skill merupakan langkah-langkah tindakan yang mendasar dan berperan besar dalam proses penanaman life skill santri untuk mencapai sasaran dan tujuan yang telah ditetapkan. ${ }^{14}$

Strategi penanaman pendidikan life skill dalam meningkatkan kemandirian santri, merupakan sebuah cara atau sebuah metode, dalam dunia pendidikan, strategi diartikan sebagai a plan, method, or series of activities designed to achieves a particular educational goal. Dengan demikian strategi

11 Lexi J. Moleong, Metodologi Penelitian Kualitatif, (Bandung: Remaja Rosdakarya Offset, 2007), hlm. 4.

12 Nana Syaodih Sukmadinata, Metode Penelitian Pendidikan, (Bandung: Remaja Rosdakarya, 2007), hlm.94

13 Lexi J. Moleong, Metodologi Penelitian Kualitatif, hlm.9

14 Ismail (ed), PBM-PAI di Sekolah, Eksistensi dan Proses Belajar Mengajar Pendidikan Agama Islam, hlm.196 
pembelajaran dapat diartikan sebagai perencanaan yang berisi tentang rangkaian kegiatan yang didesain untuk mencapai tujuan pendidikan tertentu. Ada dua hal yang perlu dicermati dari pengertian diatas: 1. Strategi penanaman pendidikan life skill dalam meningkatkan kemandirian santri, merupakan rencana tindakan (rangkaian kegiatan) termasuk penggunaan metode dan pemanfaatan berbagai sumber daya dalam pembelajaran; ${ }^{15}$ dan 2. Strategi penanaman pendidikan life skill dalam meningkatkan kemandirian santri, disusun untuk mencapai tujuan tertentu. Artinya, arah dari semua keputusan penyusunan strategi adalah pencapaian tujuan. ${ }^{16}$

Penanaman pendidikan life skill dalam meningkatkan kemandirian santri, bisa diartikan sebagai pola umum kegiatan Ustadz dan Santri dalam perwujudan kegiatan belajar mengajar untuk mencapai tujuan yang telah digariskan, pemakaian istilah ini dimaksudkan sebagai daya upaya guru dalam menciptakan suatu system lingkungan yang memungkinkan terjadinya proses belajar. Strategi Newman dan Logan dalam menanamkan pendidikan life skill untuk meningkatkan kemandirian santri di Pondok Pesantren, meliputi empat masalah, yaitu: 1. Pengidentifikasian dan penetapan spesifikasi dari kualifikasi tujuan yang akan dicapai dengan memperhatikan dan mempertimbangkan aspirasi masyarakat yang memerlukannya; 2. Pertimbangan dan pemilihan cara pendekatan utama yang dianggap ampuh untuk mencapai sasaran; 3. Pertimbangan dan penetapan langkah-langkah yang ditempuh sejak titik awal pelaksanaan sampai titik akhir pencapaian sasaran; dan 4. Pertimbangan dan penetapan tolok ukur untuk mengukur taraf keberhasilan sesuai dengan tujuan yang dijadikan sasaran. ${ }^{17}$

15 W. Gulo, Strategi Belajar Mengajar, (Jakarta: PT. Grasindo, 2002), hlm.3

16 Ismail, PBM-PAI di Sekolah, Eksistensi dan Proses Belajar Mengajar Pendidikan Agama Islam, (Yogyakarta: Pustaka Pelajar, 1998), hlm.196

17 Ismail, PBM-PAI di Sekolah, Eksistensi dan Proses Belajar Mengajar Pendidikan Agama Is-
Berdasarkan hasil penelitian, peneliti menemukan bahwa strategi penanaman pendidikan life skill dalam meningkatkan kemandirian santri baru di PM Gontor Putra II, telah sejalan dengan strategi Newman dan Logan, meliputi hal-hal berikut ini: 1 . Adanya tujuan penanaman pendidikan life skill dalam meningkatkan kemandirian santri baru di Pondok Modern Gontor Putra II; 2. Menetapkan Langkah-langkah dalam penanaman pendidikan life skill dalam meningkatkan kemandirian santri baru di PM Gontor Putra II; 3. Menggunakan beberapa pendekatan dalam penanaman pendidikan life skill untuk meningkatkan kemandirian santri baru di PM Gontor Putra II; 4. Menetapkan tolak ukur keberhasilan dalam penanaman pendidikan life skill dalam meningkatkan kemandirian santri baru, yaitu:

\section{Implementasi Penanaman Pendidikan Life Skill dalam Meningkatkan Kemandirian Santri Baru di PM Gontor Putra II.}

Implementasi penanaman pendidikan life skill dapat dilaksanakan dengan dua cara, yaitu: diinternalisasikan dalam setiap kegiatan melalui strategi penanaman pendidikan life skill yang dilaksanakan oleh Ustadz dalam proses pelaksanaan kegiatan tersebut dan melalui kegiatan-kegiatan khusus, utamanya untuk implementasi pendidikan life skill. ${ }^{18}$ Sehubungan dengan keterbatasan masalah yang ada, maka dalam hal ini akan dipaparkan pada implementasi penanaman pendidikan life skill yang diinternalisasikan pada kegiatankegiatan.

Implementasi penanaman pendidikan life skill sangat terkait dengan kondisi santri, hal ini sebagaimana prinsip pendidikan, aplikasi kurikulum dan konsep pendidikan yang mengharuskan untuk mempertimbangkan substansi kegiatan yang akan dilakukan, karakteristik santri,

lam, hlm.196

18 Tim Broad Based Education (BBE), Pendidikan Berorientasi Kecakapan Hidup (Life Skill Education), (Jakarta: Departemen Pendidikan Nasional, 2002), hlm.14 
dan kondisi pondok pesantren, serta lingkungan pondok pesantren. Oleh karena itu, aplikasi pendidikan yang mengarah kepada life skill dalam berbagai macam kegiatan yang dilakukan di pondok pesantren, tidak dapat dilakukan dengan penerapan yang sama.

Implementasi penanaman pendidikan life skill dalam meningkatkan kemandirian santri/peserta didik, menurut Departemen Pendidikan Nasional (DIKNAS), terbagi menjadi empat aspek, yaitu: 1. Personal skill; 2. Social skill; 3. Academic Skill, dan 4. Vocational Skill. ${ }^{19}$ Implementasi dengan empat aspek tersebut merupakan sebuah usaha untuk meningkatkan kepribadian, mental, potensi dan kemandirian santri baru agar mampu terampil, cakap, dan militan sesuai dengan tujuan lembaga pendidikan, sehingga di kemudian hari nanti diharapkan santri memiliki bekal pengetahuan, pengalaman dan wawasan dalam menjalani kehidupan di masa datang lebih baik lagi serta mampu mandiri sendiri tanpa harus meminta bantuan orang lain dalam menghadapi permasalahan yang dihadapinya.

Berdasarkan hasil penelitian, peneliti menemukan bahwa implementasi penanaman pendidikan life skill dalam meningkatkan kemandirian santri baru di PM Gontor Putra II, telah sejalan dengan implementasi pendidikan life skill Departemen Pendidikan dan Kebudayaan Nasional, meliputi hal-hal berikut ini: 1. Aspek Personal Skill, yang terdiri dari kegiatan sholat berjama'ah 5 waktu, tadarus al-Qur'an, tausiyah dan qiyamul lail; 2. Aspek Tinking Skill, yang terdiri dari kegiatan mahkamah, marosim, dan tandziful am, 3. Aspek Social Skill, yang terdiri dari kegiatan muawwajah, perlombaan, dan perkemahan, dan 4. Aspek Vocasional Skill, yang terdiri dari kegiatan kepramukaan, muhadhasah, muhadhoroh, kursus-kursus kesenian dan keterampilan, dan club-club olahraga.

19 Departemen Pendidikan Nasional, Pedoman Penyelenggaraan Program Kecakapan Hidup (Life Skills) Pendidikan Nonformal. (Jakarta: Ditjen Diklusepa, 2004), hlm.17
Faktor Penghambat dan Pendukung Penanaman Pendidikan Life Skill dalam Meningkatkan Kemandirian Santri Baru di PM Gontor Putra II.

Sebagaimana yang telah dijelaskan sebelumnya, bahwasanya penanaman pendidikan life skill dalam meningkatkan kemandirian santri baru di PM Gontor Putra II, memiliki tujuan untuk membentuk mental, sikap, tingkah laku, dan kepribadian muslim seutuhnya dalam mencapai kebahagiaan hidup di dunia dan akhirat. Dalam pelaksanaan penanaman pendidikan life skill, diharapkan akan terjadi proses perubahan santri baru, baik dari segi kognitif, afektif, dan psikomotoriknya, sehingga akan berubah pula tingkah laku santri baru dalam kehidupan sehariharinya.

Dalam pencapaian tujuan penanaman pendidikan life skill dalam meningkatkan kemandirian santri baru di PM Gontor Putra II, ada beberapa hal yang perlu diperhatikan yaitu faktor-faktor apa sajakah yang mendukung proses berlangsungnya pembelajaran dan faktor yang menghambatnya, yaitu sebagai berikut:

1. Faktor penghambat penanaman pendidikan life skill dalam meningkatkan kemandirian santri baru di PM Gontor Putra II, yaitu: a. Santri baru masih memiliki tingkat emosional yang masih labil, b. Belum maksimalnya pengawalan yang diberikan oleh pembimbing rayon dalam mentransformasi nilai dan filsafat hidup kepada seluruh santri baru, c. Masih sulitnya santri baru untuk menyesuaikan diri dengan kegiatan-kegiatan PM Gontor Putra II, d. Kurangnya kepedulian santri baru dalam menjaga sarana dan prasarana fisilitas kegiatan yang ada di PM Gontor Putra II, e. Daya tampung kamar santri terbatas, sehingga dapat mengganggu terhadap kegiatan-kegiatan santri baru.

2. Faktor pendukung penanaman pendidikan life skill dalam meningkatkan kemandirian santri baru di PM Gontor Putra II, yaitu a. Terintegrasinya tripu- 
sat pendidikan, yaitu sekolah, keluarga dan masyarakat, b. Integrasi jalur pendidikan formal, non-formal, dan in-formal, c. Keberadaan santri baru di PM Gontor Putra II adalah untuk menuntut ilmu dan perwujudan dari tertanamnya iman yang mengharuskan santri baru untuk mengetahui (dengan ilmu) tentang apa dan mengapa beriman serta bagaimana mengejawantahkan iman itu dalam amal, d. Transformasi penanaman pendidikan life skill dalam meningkatkan kemandirian santri baru di PM Gontor Putra II, berlangsung sepanjang tahun, dan e. Implementasi pendidikan life skill dalam meningkatkan kemandirian santri baru di PM Gontor Putra berbasis kegiatan..

\section{PENUTUP}

Strategi penanaman pendidikan life skill dalam Meningkatkan Kemandirian Santri Baru di PM Gontor Putra II, terdiri dari a. Adanya tujuan yang jelas dalam menanamkan pendidikan life skill untuk meningkatkan kemandirian santri baru, meliputi kemampuan dalam membangun kemandirian, percaya diri, pola pikir terarah, dan sikap yang dinamis; b. Menetapkan langkah-langkah/cara-cara dalam menanamkan pendidikan life skill untuk meningkatkan kemandirian santri baru, meliputi pengarahan, pelatihan, penugasan, pembiasan, dan pengawalan; c. Menggunakan pendekatan-pendekatan dalam menanamkan pendidikan life skill untuk meningkatkan kemandirian santri baru meliputi pendekatan manusiawi, pendekatan program, dan pendekatan idealisme; dan d. Menetapkan tolak ukur untuk menentukan keberhasilan dalam menanamkan pendidikan life skill untuk meningkatkan kemandirian santri baru, meliputi menguji dengan permasalahan, tugas-tugas, memutuskan pilihan, siap berkoban, tegas dalam bersikap, mengevaluasi diri, berkomunikasi dengan temannya.

Implementasi penanaman pendidikan life skill dalam meningkatkan kemandirian santri baru di PM Gontor Putra II, terdiri dari a. aspek personal skill meliputi sholat jama'ah, tadarus al-Qur'an, tausiyah, dan qiyamul lail; b. aspek tinking skill meliputi mahkamah, marosim, dan tandziful am; c. aspek social skill meliputi muawajah, perlombaan, dan perkemahan, dan d. aspek vocasional skill meliputi kepramukaan, muhadhoroh, muhadasah, kursus-kursus, dan club-club olahraga.

Faktor penghambat dan pendukung penanaman pendidikan life skill dalam meningkatkan kemandirian santri baru di PM Gontor Putra II, terdiri dari a. Faktor penghambat, meliputi: Santri baru masih memiliki tingkat emosional yang masih labil, belum maksimalnya pengawalan terhadap santri baru yang diberikan oleh pembimbing rayon, masih sulitnya santri baru untuk menyesuaikan diri dengan kegiatan-kegiatan Pondok, kurangnya kepedulian santri baru dalam menjaga sarana dan prasarana, dan daya tampung kamar santri terbatas, sehingga dapat mengganggu terhadap kegiatan-kegiatan santri baru. b. Faktor pendukung, meliputi: terintegrasinya tripusat pendidikan, integrasi jalur pendidikan formal, nonformal, dan in-formal, keberadaan santri baru di PM Gontor Putra II adalah untuk menuntut ilmu, transformasi penanaman pendidikan life skill dalam meningkatkan kemandirian santri baru berlangsung sepanjang tahun, dan implementasi pendidikan life skill dalam meningkatkan kemandirian santri baru di PM Gontor Putra berbasis kegiatan.

\section{DAFTAR PUSTAKA}

Ali, Suryadharma. 2013. Mengawal Tradisi Meraih Prestasi; Inovasi dan Aksi Pendidikan Islam. Malang: UIN-Maliki Press

Departemen Pendidikan Nasional. 2004. Pedoman Penyelenggaraan Program Kecakapan Hidup 
(Life Skills) Pendidikan Nonformal. Jakarta: Ditjen Diklusepa.

Gulo, W. 2002. Strategi Belajar Mengajar. Jakarta: PT. Grasindo.

Gymnastiar, Abdullah. 2003. Malu Jadi Benalu. Bandung: MQ Publishing.

Helmawati. 2014. Pendidikan Keluarga Teoritis dan Praktis. Bandung: Remaja Rosdakarya.

Ismail. 1998. PBM-PAI di Sekolah, Eksistensi dan Proses Belajar Mengajar Pendidikan Agama Islam. Yogyakarta: Pustaka Pelajar.

Juwariyah. 2008. Pendidikan Moral dalam Puisi Imam Syafi'i dan Ahmad Syauqi. Yogyakarta: Bidang Akademik.

Moleong, Lexi J. 2006. Metodologi Penelitian Kualitatif. Bandung: Remaja Rosdakarya.

Naim, Ngainun. 2012. Character Building. Jogjakarta: Ar-Ruzz Media.

Suharto, Ahmad. 2016. Senarai Kearifan Gontory (Kata Bijak Para Perintis dan Masyayikh Gontor). Yogyakarta: YPPWP Guru Muslich.

2017. Melacak Akar Filosofis Pendidikan Gontor (Kajian Metamorfosis Syajarah Thayyibah Gontor). Yogyakarta: Nabela.

Sukmadinata, Nana Syaodih. 2007. Metode Penelitian Pendidikan. Bandung: Remaja Rosdakarya.

Tim Broad Based Education. 2002. Pendidikan Berorientasi Kecakapan Hidup (Life Skill Education). Jakarta: Departemen Pendidikan Nasional.

Tim Kreatif al-Ikhlâs, Al-Qur'an Terjemah Al-Ikhlâs, (Jakarta Pusat: Samad, t.h) 